\title{
Tatovert norsk turist med feber og utslett
}

\author{
En mann i 40-årene fikk under en feriereise i Asia utført en tatovering. \\ Under oppholdet utviklet han utslett og etter hjemkomsten allmenn- \\ symptomer. Relevant prøvetaking ble avgjørende for å kunne stille rett \\ diagnose.
}

En tidligere frisk mann i 40-årene utviklet feber og utslett i en tatovering han hadde fått utført $i$ utlandet. Utslettet var ømt og hadde oppstått få dager etterpå. Etter hjemkomst tre uker senere utviklet han feber, hodepine og leddsmerter. Han oppsøkte legevakten, der det ble ordinert dikloksacillin på mistanke om impetigo.

Hudinfeksjoner er som regel forårsaket av gule stafylokokker eller betahemolytiske streptokokker. Det kliniske bildet kan variere fra impetigo, erysipelas, cellulitt og abscesser til sepsis. Det er estimert at det i $1-5 \%$ av alle tatoveringer oppstår bakterielle hudinfeksjoner(1).

Ved mistanke om stafylokokkindusert hudinfeksjon er behandling med dikloksacillin førstevalg (2).

Fem dagers behandling med dikloksacillin hadde ingen effekt. Tvert imot ble tilstanden forverret, og fastlegen ba om vurdering som øyeblikkelig hjelp ved lokalsykehuset. Ved undersøkelse i mottagelsen var pasienten slapp, hadde feberfølelse, leddsmerter og hodepine. Det ble observert erytematøse papler, små kruster og pustler svarende til tatovert hudområde (fig 1) samt enkelte elementer spredt på thorax og lår. Han ble derfor innlagt $i$ infeksjonsmedisinsk avdeling under den tentative diagnosen infeksjon.

Vakthavende infeksjonsmedisiner sikret allerede på dette tidspunktet prøvemateriale fra pustel på penselprøve til dyrking med henblikk på vanlige sårpatogene bakterier, mykobakterier og sopp. Det ble også tatt prøve til herpes simplex virus (HSV)-polymerasekjedereaksjon (PCR). Bortsett fra pollenallergi og nikkelallergi var pasienten tidligere frisk. Han hadde ved tidligere anledninger fått utført tatovering uten komplikasjoner.

Blodprøver ved innleggelsen viste senkningsreaksjon $48 \mathrm{~mm}(1-12 \mathrm{~mm}), C$-reaktivt protein (CRP) $58,9 \mathrm{mg} / \mathrm{l}(0,0-4,0 \mathrm{mg} / \mathrm{ll})$, hemoglobin $14,1 \mathrm{~g} / \mathrm{l}(13,4-17,0 \mathrm{~g} / \mathrm{l})$, leukocytter 9,2 $10 \% / \mathrm{l}\left(3,5-10,0 \cdot 10^{9} / \mathrm{l}\right)$, ASAT $59 \mathrm{U} / \mathrm{l}$ (15-45 U/l), ALAT $92 \mathrm{U} / \mathrm{l}$ (10-70 U/l), ALP 117 U/l (35-105 U/l), GT 134 U/l (15-115 U/ 1). Differensialtelling av hvite blodceller viste lett økning av monocytter $1,1 \cdot 10^{9} / \mathrm{l}(0,2-0,8$ - $10^{\circ} / \mathrm{l}$. Øvrige blodprøver inklusive trombocytter var normale.
Han var afebril innleggelsesdagen, men fikk dagen etter feber opp til $38,8^{\circ} \mathrm{C}$. Det ble derfor tatt blodkultur. Pasienten var $i$ god allmenntilstand, og man valgte å la være å starte empirisk behandling.

Tatovering kan gi ulike komplikasjoner, både lokale og systemiske infeksjoner samt ulike immunologiske reaksjoner. Det er vanlig med en forbigående lett inflammatorisk hudreaksjon med kløe og hevelse i noen uker etterpå (3). Dette kan skyldes en normal immunreaksjon mot tatoveringsblekket eller være en reaksjon på de multiple nålestikk som prosedyren innebærer. Som regel vil slike reaksjoner ikke føre til kontakt med helsetjenesten.

Smitte med blodbårne virus som hepatitt B-virus (HBV), hepatitt C-virus (HCV) og humant immunsviktvirus (hiv) gjennom infiserte nåler er alvorlige og velkjente komplikasjoner. Vår pasient hadde lett forhøyde transaminaser, noe som kan ses ved akutt hepatitt og akutt hivinfeksjon, men sykdomsbildet ga liten mistanke om en slik komplikasjon. Det ble heller ikke påvist antistoff mot hepatitt B-virus, hepatitt $\mathrm{C}$-virus eller hiv. Økende bruk av engangsnåler og bedre hygiene har redusert risikoen for smitte av blodbårne sykdommer betydelig (4).

Andre sykdommer som i sjeldne tilfeller har vært overført ved tatovering, inkluderer verruca vulgaris (5), molluscum contagiosum (6) og lepra (7).

To dager etter innleggelsen utviklet mannen små, ømme, nodulære lesjoner på underarmer og legger. Under mistanke om erythema nodosum fikk pasienten prednisolon $10 \mathrm{mg} \times 3$ og ibuprofen $600 \mathrm{mg} \times 2$ daglig, med initial bedring av allmenntilstanden.

Det er få rapporter om erythema nodosum etter tatovering (8). I Norge er streptokokkinfeksjon i hals eller akutt sarkoidose blant de vanligste underliggende tilstander som kan gi utbrudd av erythema nodosum, men ofte kan årsaken ikke påvises. Tidligere var tuberkulose en ikke uvanlig utløsende årsak.

Fire dager etter innleggelsen ble pasienten tilsett av hudleger, som var usikre på årsaken

\author{
Kristine Bø \\ kristine.bo@ous-hf.no \\ Seksjon for hudsykdommer \\ Oslo universitetssykehus, Rikshospitalet \\ Kristin Helene Skullerud* \\ Seksjon for hudsykdommer \\ Oslo universitetssykehus, Rikshospitalet
}

Anne Torunn Mengshoel*

Avdeling for mikrobiologi

Oslo universitetssykehus

\section{Vegard Eldholm}

Avdeling for molekylærbiologi

Folkehelseinstituttet

\section{Arne Broch Brantsæter}

Infeksjonsmedisinsk avdeling Oslo universitetssykehus, Ullevål

og

Nasjonal behandlingstjeneste for CBRNE-medisin Oslo universitetssykehus

* Nåværende adresser:

K.H. Skullerud, Olafiaklinikken,

Seksjon for venerologi

Oslo universitetssykehus

A.T. Mengshoel, Nasjonalt referanselaboratorium for mykobakterier

Folkehelseinstituttet

Kristine Bø og Kristin Helene Skullerud har begge bidratt som førsteforfattere. 


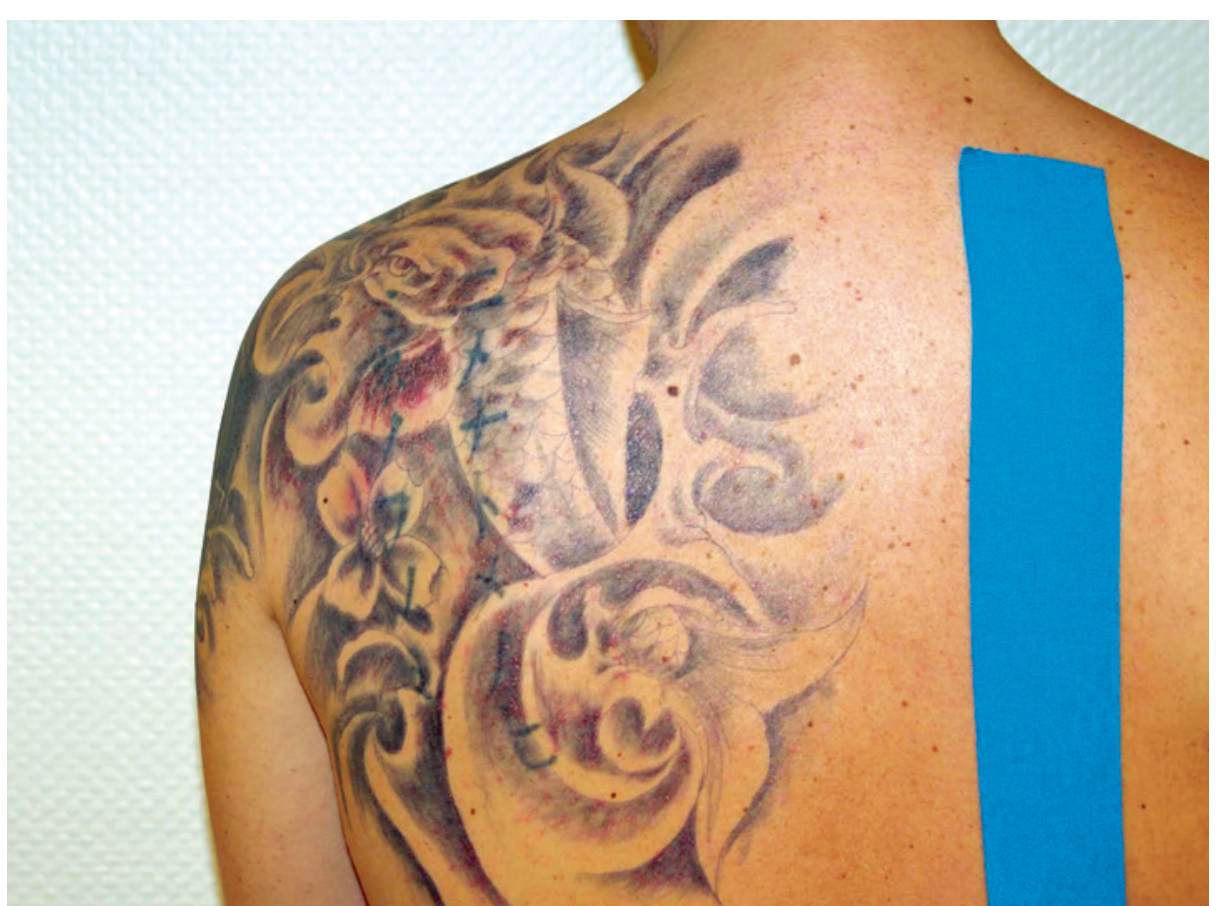

Figur 1 Bildet er tatt ved innleggelsen og viser utslettet med erytematøse papler, små kruster og pustler svarende til tatovert hudområde. Foto: Arild Mæland. Bilde fra pest-POSTEN nr. 3/2013, gjengitt med tillatelse

til utslettet. Diagnosene mikrobielt eksem, follikulitter og erythema nodosum ble stilt tentativt, og lokalbehandling med betametasonkrem med kliokinol ble anbefalt.

Dette førte til forverring av utslettet, og denne behandlingen ble seponert.

Betegnelsen «mikrobielt eksem» har varierende betydning, men den brukes som regel for å betegne et eksem som er sekundærinfisert med bakterier eller sopp. Noen bruker mikrobielt eksem synonymt med nummulat eksem, en eksemvariant som ofte er impetiginisert med gule stafylokokker. Follikulitter (hårsekksbetennelse) kan skyldes infeksjon med for eksempel bakterier eller sopp, men kan også ha ikke-infeksiøs etiologi som traume, inflammasjon eller okklusjon.

Andre typer hudreaksjoner kan også oppstå etter tatovering, for eksempel kontaktallergisk reaksjon overfor noen av de mange ulike innholdsstoffene i tatoveringsblekket, som pigmenter og metaller. Disse vil kunne gi kløende eksematøst utslett, men også andre typer betennelser i tatovert område (9).

Det var nærliggende å vurdere kontaktallergisk utslett hos vår pasient, men utvikling av feber og påvirket allmenntilstand er ikke typisk ved slike reaksjoner. Som oftest er det rødt pigment som er årsak til kontaktallergisk dermatitt ved tatovering (10), men flere fargepigmenter kan gi dette. Utredning med standardiserte epikutantester vil ikke nødvendigvis påvise utløsende allergen, noe som kan skyldes at danning av hapten skjer i selve dermis etter tatoveringen (11). I til- legg blir testing vanskelig fordi det ikke foreligger standardiserte epikutantester med alle de mange ulike ingrediensene som finnes i tatoveringsblekk.

Fotosensitive reaksjoner i huden er relativt hyppig forekommende og kan opptre ved flere ulike tatoveringsfarger (12). Lichenoide dermatitter, granulomatøse betennelser (inkludert sarkoidose), forverring av psoriasis eller eksem og utvikling av keloid er andre hudreaksjoner som har vært rapportert etter tatovering (13).

Alminnelig bakteriologisk dyrking av prøve fra utslettet viste normal hudflora. HSV-PCR var negativ, likeså blodkulturene. Omtrent en uke etter innleggelsen rapporterte laboratoriet om vekst av hurtigvoksende mykoRGM) fra en pustel. Isolatet ble identifisert som M. chelonae/M. abscessus ved hjelp av 16S rDNA-sekvensering.

Pasienten ble deretter gitt etambutol 800 mg daglig og klaritromycin 500 mg $\times 2$.

Ved mistanke om mykobakterieinfeksjon i hud bør det i tillegg til vanlig bakteriologisk prøve sendes prøve til dyrking av mykobakterier. Puss, aspirat eller biopsi sendes på sterilt glass uten tilsetning. Penselprøve i bakteriologisk transportmedium kan benyttes hvis det er lite prøvemateriale tilgjengelig. Relevante kliniske opplysninger vil være til hjelp for laboratoriets videre arbeid med prøven.

Vår pasient fikk sin diagnose stilt relativt bakterier (rapidly growing mycobacteria, tidlig fordi infeksjon med hurtigvoksende mykobakterier ble inkludert blant differensialdiagnosene allerede ved innleggelsen, og fordi mikrobiologisk laboratorium fikk informasjon om dette.

Isolatet ble endelig identifisert som M. abscessus ved hjelp av GenoType Mycobacterium CM (commen)-test (Hain Lifescience, Nehren, Tyskland). Dette er en genetisk test der man benytter $23 S$ rRNA som målgen og der de vanligste ikke-tuberkuløse mykobakteriene blir identifisert ved hjelp av en revers hybridisering til aktuelle prober.

Resistensbestemmelse med Etest (bioMerieux, Frankrikel viste følsomhet for klaritromycin og resistens for etambutol. Buljongmikrofortynning er anbefalt metode (14) for resistensbestemmelse av hurtigvoksende mykobakterier, men var ikke tilgjengelig i Norge på dette tidspunktet. Ved hjelp av denne metoden kan man påvise induserbar makrolidresistens, $i$ motsetning til ved Etest-metoden.

M. abscessus kan gi både lokale og systemiske infeksjoner. Immunsupprimerte pasienter er særlig utsatt for å få et alvorlig sykdomsforløp med lungebetennelse, kronisk lymfadenitt eller affeksjon av hud, bløtvev og skjelett. Kronisk lungesyke, for eksempel pasienter med cystisk fibrose, kan også få alvorlig lungebetennelse med denne bakterien.

Siden mikroben var resistent mot etambutol, ble dette medikamentet seponert, og pasienten fortsatte med klaritromycin som monoterapi i tre måneder. I starten av kuren opplevde han økende ømhet $i$ noduli på ekstremiteter, entesitt, dyspné og økt tretthet. Prednisolon ble gitt $i$ nedtrappende doser for å dempe betennelsen. Det var ingen oppvekst av mykobakterier i prøve fra utslettet tatt tre uker etter påbegynt antibiotikabehandling.

En måned etter fullført behandling var det markert klinisk bedring, men pasienten hadde utviklet en hudfarget, $1 \times 1 \mathrm{~cm}$ noduløs lesjon i venstre aksille. En $5 \mathrm{~mm}$ stansebiopsi av den intrakutane oppfyllingen viste granulomatøs betennelse med fremmedlegemereaksjon. Farging med auraminrhodamin viste ikke tegn til syrefaste staver. Det ble ikke utført dyrking av hudbiopsi med henblikk på mykobakterier. Klinisk kontroll etter syv og 12 måneder viste mildt erytem og noen få papler i tatovert område.

Etter fullført behandling ble bakterieisolatets genom sekvensert (ENA sample accession: ERS7442656). Nærmere undersøkelser av utvalgte gener viste at isolatet tilhørte M. abscessus subspecies massiliense. Det hadde verken ervervet eller induserbar resistens mot makrolider. 


\section{Diskusjon}

Hurtigvoksende mykobakterier tilhører gruppen ikke-tuberkuløse mykobakterier og er vanlig forekommende $\mathrm{i}$ våre omgivelser, for eksempel i jord, vann og støv. I medisinsk litteratur rapporteres det om økende forekomst av infeksjoner forårsaket av hurtigvoksende mykobakterier hos både immunsupprimerte og immunkompetente personer (15). Direkte smitte mellom mennesker med denne gruppen bakterier er sannsynligvis svært sjeldent, men det kan muligens forekomme mellom pasienter med cystisk fibrose (16).

Bruk av kontaminert tatoveringsblekk og ikke-sterilt vann til uttynning av blekket har tidligere forårsaket utbrudd av hurtigvoksende mykobakterier i ulike deler av verden (17). Andre utbrudd har oppstått etter kosmetisk kirurgi (18). I Skottland ble det i etterkant av 25 rapporter om infeksjoner med hurtigvoksende mykobakterier etter tatovering gjort grundige miljøundersøkelser. Det var ikke mulig å fastslå smittekilde i alle tilfeller, men den hyppigste antatte årsak til infeksjon var fortynning av svart tatoveringsblekk med vanlig vann fra springen (19).

Siden vår pasient var blitt tatovert $\mathrm{i}$ utlandet, men ble behandlet i Norge, ble det ikke utført videre epidemiologiske undersøkelser i dette tilfellet. I en studie fra Norge ble det påvist bakteriell kontaminering $\mathrm{i}$ syv av totalt 12 prøver fra fargeløsninger brukt til tatovering, men det ble ikke undersøkt spesielt med tanke på mykobakterier (20).

Pasienten ble først behandlet med etambutol og klaritromycin, men det førstnevnte ble seponert på grunn av påvist resistens. $M$. $a b$ scessus har iboende resistens overfor etambutol. Resistens for makrolider kan skyldes ervervet ( $r r l$-genmutasjoner) eller induserbar resistens. Induserbar resistens ses hos subtyper av M. abscessus som har et funksjonelt erm(41)-gen. Isolatet hos vår pasient hadde ingen $r r l$-genmutasjon og heller ikke et funksjonelt erm(41)-gen, noe som er karakteristisk for $M$. abscessus subspecies massiliense.

Det foreligger ikke god vitenskapelig dokumentasjon for optimal behandling ved lungesykdom og andre systemiske infeksjoner med M. abscessus, men det er vanlig å anbefale flere måneder lang kombinasjonsbehandling med antimykobakterielle midler $(21,22)$. Makrolider, enten azitromycin eller klaritromycin, har en sentral plass dersom det ikke foreligger resistens.

Ved overflatiske hudinfeksjoner er det uvisst om det er nødvendig å kombinere medikamenter, men de fleste anbefaler kombinasjonsbehandling $(21,22)$ for å unngå resistensutvikling under behandling. Hos vår immunkompetente pasient med overflatisk hudinfeksjon ble monoterapi med klaritromycin ansett som tilstrekkelig. Basert på klinisk vurdering og negativ dyrking etter tre måneder ble behandlingen stoppet - uten at det førte til progrediering eller tilbakefall av symptomer.

Fravær av induserbar makrolidresistens hos bakterieisolatet var sannsynligvis avgjørende for det vellykkede behandlingsresultatet hos denne pasienten. Ut fra det at han hadde systemiske symptomer kan det imidlertid diskuteres om han burde fått kombinasjonsbehandling for å unngå resistensutvikling og disseminering av sykdommen.

Det er blitt svært vanlig å få utført tatoveringer både i Norge og andre land. Mange opplever bivirkninger fra huden, oftest i form av infeksjon, granulomatøs reaksjon, allergi eller godartede svulster $(1,23)$. Hurtigvoksende mykobakterier er en ikke uvanlig årsak til infeksjon i tatoveringer, og denne kasuistikken illustrerer at korrekt prøvetaking og mikrobiologisk undersøkelse kan være avgjørende for riktig diagnose og behandling.

Pasienten har gitt samtykke til at artikkelen blir publisert.

\section{Kristine Bø (f. 1965)}

er spesialist i hud- og veneriske sykdommer og overlege.

Forfatter har fylt ut ICME-skjemaet og oppgir ingen interessekonflikter.

\section{Kristin Helene Skullerud (f. 1974)}

er spesialist i hud-og veneriske sykdommer og overlege.

Forfatter har fylt ut ICME-skjemaet og oppgir ingen interessekonflikter.

\section{Anne Torunn Mengshoel (f. 1966)}

er spesialist i medisinsk mikrobiologi og overlege.

Forfatter har fylt ut ICME-skjemaet og oppgir

ingen interessekonflikter.

\section{Vegard Eldholm (f. 1980)}

har en ph.d.-grad i molekylær mikrobiologi og er forsker

Forfatter har fylt ut ICME-skjemaet og oppgir ingen interessekonflikter.

\section{Arne Broch Brantsæter (f. 1959)}

er spesialist i indremedisin og i infeksjonssykdommer og overlege.

Forfatter har fylt ut ICME-skjemaet og oppgir ingen interessekonflikter.

\section{Litteratur}

1. Laux P, Tralau T, Tentschert J et al. A medicaltoxicological view of tattooing. Lancet 2016; 387 $395-402$

2. Nasjonale faglige retningslinjer for antibiotikabruk i primærhelsetjenesten. Utgitt 11/2012. IS-2010. Oslo: Helsedirektoratet, 2012.

3. Høgsberg T, Hutton Carlsen K, Serup J. High prevalence of minor symptoms in tattoos among a young population tattooed with carbon black and organic pigments. J Eur Acad Dermatol Venereol 2013; 27: 846-52
4. Urbanus AT, van den Hoek A, Boonstra A et al. People with multiple tattoos and/or piercings are not at increased risk for HBV or HCV in The Netherlands. PLoS One 2011; 6: e24736.

5. Ramey K, Ibrahim J, Brodell RT. Verruca localization predominately in black tattoo ink: a retrospec tive case series. J Eur Acad Dermatol Venereol 2016; 30: e34-6.

6. Salmaso F, Gnecchi L, Gianotti R et al. Molluscum contagiosum on a tattoo. Acta Derm Venereol 2001; 81: 146-7.

7. Ghorpade A. Inoculation (tattoo) leprosy: a report of 31 cases. J Eur Acad Dermatol Venereol 2002; 16: $494-9$

8. Wollina U, Gruner M, Schönlebe J. Granulomatous tattoo reaction and erythema nodosum in a young woman: common cause or coincidence? J Cosmet Dermatol 2008; 7: 84-8

9. Gunnarsson GL, Eiriksdottir HB, Knapskog E et al. Tatoveringsblekk - en underkjent helsefare? Tidsskr Nor Legeforen 2014: 134: 274.

10. Brady BG, Gold H, Leger EA et al. Self-reported adverse tattoo reactions: a New York City Central Park study. Contact Dermat 2015; 73: 91-9.

11. Serup J. Hutton Carlsen K. Patch test study of 90 patients with tattoo reactions: negative outcome of allergy patch test to baseline batteries and culprit inks suggests allergen(s) are generated in the skin through haptenization. Contact Dermat 2014; 71: 255-63.

12. Hutton Carlsen K, Serup J. Photosensitivity and photodynamic events in black, red and blue tattoos are common: A 'Beach Study'. J Eur Acad Dermatol Venereol 2014: 28: 231 - 7.

13. Islam PS, Chang C, Selmi $C$ et al. Medical complications of tattoos: A comprehensive review. Clin Rev Allergy Immunol 2016; 50: 273-86.

14. CLSI standard M24-A2. Susceptibility Testing of Mycobacteria, Nocardiae, and Other Aerobic Actinomycetes; Approved Standard. 2. utg. Wayne, PA: Clinical and Laboratory Standards Institute, 2011.

15. De Groote MA, Huitt G. Infections due to rapidly growing mycobacteria. Clin Infect Dis 2006; 42 1756-63.

16. Bryant JM, Grogono DM, Greaves D et al. Wholegenome sequencing to identify transmission of Mycobacterium abscessus between patients with cystic fibrosis: a retrospective cohort study. Lancet 2013: 381: 1551-60.

17. Falsey RR, Kinzer MH, Hurst S et al. Cutaneous inoculation of nontuberculous mycobacteria during professional tattooing: a case series and epidemiologic study. Clin Infect Dis 2013; 57: e143-7.

18. Green DA, Whittier S, Greendyke W et al. Outbreak of rapidly growing nontuberculous mycobacteria among patients undergoing cosmetic surgery in the Dominican Republic. Ann Plast Surg 2017; 78 $17-21$

19. Conaglen PD, Laurenson IF, Sergeant A et al. Systematic review of tattoo-associated skin infection with rapidly growing mycobacteria and public health investigation of a cluster in Scotland, 2010. Euro Surveill 2013; 18: 20553

20. Charnock C. Tatoveringsløsninger forurenset av bakterier. Tidsskr Nor Lægeforen 2004; 124: $933-5$

21. Griffith DE, Aksamit T, Brown-Elliott BA et al. An official ATS/IDSA statement: diagnosis, treatment, and prevention of nontuberculous mycobacterial diseases. Am J Respir Crit Care Med 2007; 175: $367-416$

22. Brown-Elliott BA, Nash KA, Wallace RJ jr. Antimicrobial susceptibility testing, drug resistance mechanisms, and therapy of infections with nontuberculous mycobacteria. Clin Microbiol Rev 2012: 25: 545-82

23. Wenzel SM, Rittmann I, Landthaler $M$ et al. Adverse reactions after tattooing: review of the literature and comparison to results of a survey. Dermatology 2013; 226: 138-47.

Mottatt 24.8. 2016, første revisjon 21.11. 2016, godkjent 5.12. 2016. Redaktør: Ketil Slagstad. 